\title{
A Estação: ideologia burguesa e sua denúncia em Quincas Borba
}

\author{
A Estação: bourgeois ideology denounced in Quincas Borba
}

\author{
Juracy Assmann Saraiva \\ Universidade Feevale -Feevale - Novo Hamburgo- Rio Grande do Sul - Brasil
}

\begin{abstract}
Resumo: O artigo enfoca o contexto da instalação do mercado editorial no Brasil, a partir da década de 1870, e analisa o papel do periódico $A$ Estação na difusão de práticas culturais oriundas da Europa, particularmente da França, e na formação de leitores. O periódico, proveniente da Alemanha, era composto por duas partes: um suplemento de moda, que informava as tendências parisienses sobre vestuário, decoração, etiqueta e comportamento, e um suplemento literário, produzido no Brasil, em que Machado de Assis publicou contos, poemas, novelas e o romance Quincas Borba. O confronto das duas versões de Quincas Borba, a primeira em fascículos e a segunda em livro, permite constatar que Machado reconhece serem distintos os leitores de cada uma das versões, estando as mudanças que ele introduz relacionadas a esse aspecto. Entretanto, em ambas as versões, transparece a denúncia contra a subserviência cultural e o apego à aparência, manifestando-se uma ruptura em relação aos valores do veículo em que a primeira versão se inscreve.
\end{abstract}

Palavras-chave: Contexto. A Estação. Cultura. Machado de Assis. Quincas Borba.

Abstract: This article focuses on the context in which the editorial market began in Brazil, in the 1870s, and analyzes the role of the periodical $A$ Estação in disseminating cultural practices from Europe, particularly from France, and in getting people to read. The periodical from Germany consisted of two parts: a fashion supplement, which informed about the Parisian trends regarding clothes, decoration, etiquette and behavior, and a literary supplement produced in Brazil, in which Machado de Assis published short stories, poems, serialized stories and the novel Quincas Borba. Confronting the two versions of Quincas Borba, the first in fascicles and the second in book form, it can be seen that Machado realizes that each version has different readers, and the changes that he introduces are related to this aspect. However, in both versions, one notices the denunciation against cultural subservience and the attachment to appearance and it expresses a break with the values of the vehicle in which the first version is published.

Keywords: Context. A Estação. Culture. Machado de Assis. Quincas Borba. 


\section{Contexto de circulação de $A$ Estação}

A partir de 1870, empreendedores estrangeiros identificaram, no Rio de Janeiro, um promissor mercado na área das letras, embora enfrentassem dificuldades devido à necessidade da importação de equipamentos, da ausência de um sistema de produção, da precária distribuição e circulação de livros e revistas, da escassez de mão de obra especializada e, sobretudo, devido ao analfabetismo, que interferia na formação de leitores.

Paralelamente ao comércio livreiro, que, nessa década, contava com trinta livrarias ${ }^{1}$ - embora só $30 \%$ da população brasileira soubesse $\operatorname{ler}^{2}-$, outras formas de expressão artística desenvolviam-se, atendendo às exigências de um público apreciador de arte. Com efeito, a elite carioca, em consonância com "valores estéticos oriundos do avanço da burguesia no Ocidente europeu" (SODRÉ, 1982, p. 23) valorizava espetáculos musicais e encenações dramáticas, sendo criados locais como o Ginásio Dramático, o Teatro São Pedro, o São Januário e o Lírico Fluminense (MASSA, 1971, p. 94).

Entretanto, a expansão do ambiente cultural ocorria simultaneamente a conflitos provocados por fatores políticos, econômicos e sociais: a eclosão do movimento republicano, os embates devido à escravatura, os atritos do governo imperial com a Igreja Católica e com o Exército exacerbaram, a partir de 1870, um clima de instabilidade, que viria redundar na instalação, em 1889, de novo sistema de governo (FAUSTO, 2012).

No dia 3 de dezembro de 1870 , os republicanos divulgaram, no jornal $A$ República, o "Manifesto Republicano", considerado o marco inicial desse movimento. Ele ganhou uma feição organizada

\footnotetext{
${ }^{1}$ Entre as livrarias, constavam a Enciclopédica, a Cruz Coutinho, a Casa de uma Porta Só, a Luso-Brasileira, a Dupont e Mendonça, a Clássica, a Econômica, a Correa de Mello, salientando-se o poder comercial da Imperial Typografia Dous de Dezembro de Paula Brito e das casas editoriais Laemmert, Garnier e de Francisco Alves de Oliveira (BORGES, 2005, p. 79).

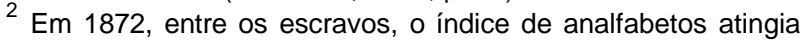
$99,9 \%$ e, entre a população livre, aproximadamente $80 \%$, subindo para mais de $86 \%$ quando só as mulheres eram consideradas. Somente $16,85 \%$ da população, entre seis e quinze anos, frequentava escolas. Havia apenas doze mil matriculados em colégios secundários. Entretanto, calcula-se que chegava a oito mil o número de pessoas com educação superior no país (FAUSTO, 2012).
}

no Partido Republicano Paulista, que se apoiava na cafeicultura e visava à defesa da federação como única forma de separar a Igreja do Estado, de garantir às províncias o controle da política econômica e de descentralizar a renda. Vinculada a esse movimento político, a questão abolicionista ganhou força a partir da década de 1880, com a aparição de associações e de jornais que defendiam a libertação dos escravos e com o avanço da propaganda, que motivou pessoas de diversas condições sociais a aderir às campanhas. A lei da abolição da escravatura, sancionada pela princesa Isabel em 13 de maio de 1888, e que fora aprovada por grande maioria parlamentar, gerou insatisfação entre a classe dominante, promoveu o divórcio entre fazendeiros e a Coroa e multiplicou o número de proprietários favoráveis às ideias republicanas, o que contribuiu para a queda da monarquia no ano seguinte.

No âmbito econômico, o país investia na agricultura e buscava meios de desenvolver a indústria. Por volta de 1870 , a incorporação maciça de imigrantes, sobretudo de italianos, transformou o setor agrícola, e o café, principal produto brasileiro para a exportação, trouxe divisas que provocaram um expressivo desenvolvimento econômico. Paralelamente, a imigração e o pagamento de salário pela mão de obra possibilitaram as bases para a formação de um mercado, tanto de trabalho quanto de consumo, e a expansão industrial era comprovada pela instalação de indústrias no país - que saltaram de 175 estabelecimentos, em 1874, para mais de 600 em 1880 -, e pela implantação de uma malha ferroviária, por todo o território nacional (FAUSTO, 2012). Entretanto, o início da industrialização, junto à libertação dos escravos, foi responsável também pela desestabilização de grande parcela da população, incapaz de corresponder às exigências do mercado de trabalho. Esse problema somava-se à insatisfação de latifundiários que, com a abolição, sentiam-se usurpados em seu direito à propriedade, o que gerou a retirada do apoio à política do governo monárquico.

A instabilidade social contribuiu para enfraquecer o poder da monarquia, cuja estrutura vinha sendo abalada pelo embate de forças entre o 
Exército e representantes da classe política; os conflitos entre a Igreja Católica e o governo, que apoiava a maçonaria; a rejeição à Princesa Isabel e ao Conde D'Eu, também essa parcialmente vinculada a aspectos religiosos; a insatisfação dos grandes latifundiários devido à abolição da escravatura. Esses fatos criaram as condições propícias à derrocada do Império e à instalação do regime republicano.

Nesse contexto de turbulência, a Tipografia $\mathrm{H}$. Lombaerts pôs em circulação a revista $A$ Estação, cuja proposta editorial não enfocava as crises políticas e econômicas, os inequívocos problemas educacionais - de que os raros indivíduos alfabetizados eram uma prova -, tampouco criticava a arcaica estrutura política. Mas, embora estivesse imune às circunstâncias sócio-históricas, a revista encontrava eco na emergente classe burguesa que se identificava com o modo de vida europeu que nela era representado.

\section{Ideologia, nas entrelinhas da moda e da literatura}

A revista $A$ Estação, publicação quinzenal, circulou no Brasil no período de 15 de janeiro de 1879 a 15 de fevereiro de 1904, "como a continuação da publicação francesa La Saison" (MEYER, 1993, p.76). Esse periódico fora distribuído no país entre os anos de 1872 e 1878, também pela Lombaerts, livraria e tipografia alemã que tinha filial instalada na prestigiada Rua do Ouvidor, no Rio de Janeiro. Além de fazer a importação de jornais e de revistas, a Lombaerts prestava serviços de impressão por encomenda e tornou-se responsável pela edição da revista $A$ Estação.

A Estação era um segmento da revista ilustrada alemã Die Modenwelt, publicada pela editora Lipperheide, companhia concentrada em Berlim e Leipzig, que produzia periódicos com a colaboração de outras editoras da Europa, com o objetivo de divulgar a moda parisiense e os bens de consumo europeus pelo ocidente (SILVA, 2009, p. 2). A Die Modenwelt era traduzida em quinze idiomas, distribuída em vinte países, sob diferentes títulos, de acordo com o local em que circulava, constituindo, dessa forma, uma rede "de orientação cultural, com aspirações transnacionais" (SILVA, 2009, p. 21).

Em sua versão brasileira, $A$ Estação apresentava o "Jornal de Moda", importado da matriz alemã para todos os periódicos, sem considerar a diferença entre os países onde esses circulavam. Tinha, porém, uma peculiaridade: oferecia aos leitores o "Suplemento Literário", que era produzido especialmente para as edições que circulavam no Brasil.

O "Suplemento Literário", introduzido em março de 1879, era composto por poemas, contos, romances, narrativas seriadas de autores consagrados da literatura brasileira, dos quais são exemplos Machado de Assis, Olavo Bilac, Raymundo Correa, Júlia Lopes de Almeida, Arthur Azevedo, Luiz Guimarães Junior, Luiz Delfino, Raimundo Correa, Lucio de Mendonça. Alguns autores estrangeiros, como Alphonse Karr, Arséne Houssane, Manuel Maria du Bocage, Leon Tolstoi, Guy de Maupassant, Edgar Allan Poe, tiveram textos traduzidos e publicados no suplemento brasileiro. Além das produções literárias, o suplemento apresentava críticas e crônicas teatrais, resenhas de obras literárias, sugestões de leitura, conselhos sobre utilidades domésticas, seções de entretenimento, partituras musicais e obras pictóricas.

Essas ilustrações, que compunham a sessão "de belas artes, vinham da revista alemã Illustrierte Frauen Zeitung, também pertencente a Lipperheide" (SILVA, 2009, p. 18), na forma de pranchas de xilogravuras e litogravuras, e eram entalhadas em Berlim ou Leipzig. Consequentemente, apesar do caráter localista que the era conferido por meio do "Suplemento Literário", o veículo mantinha o vínculo com a matriz europeia, já que as imagens pictóricas criavam um elo com o "Jornal de Moda", cujas mensagens, assumidamente importadas, reforçavam o caráter multinacional da revista. Assim, ilustrações produzidas na Alemanha disseminavam a moda parisiense e dividiam espaço com textos verbais, escritos em português ou traduzidos para a língua portuguesa, dos quais são exemplo a "Crônica da 
Moda" ou o "Correio da Moda", publicados na capa das edições de $A$ Estação.

Os valores manifestados na parte da moda da revista $A$ Estação, entre os quais os da elegância e do bom gosto, encontravam, no Brasil, um público constituído pela emergente classe burguesa, que se identificava com os padrões da cultura europeia. 0 subtítulo do periódico - "Jornal ilustrado para a família" - assinalava a valorização do núcleo familiar, em que a mulher constituía o alicerce da formação de crianças e jovens, e explicitava, ainda, sua orientação moralizante. Além disso, a concepção da revista - em que as crônicas de moda se agregavam a conselhos sobre decoração, instruções sobre trabalhos manuais e boas maneiras -, os editoriais, bem como as cartas aos leitores e as ilustrações de moda - em que predominavam figuras de mulheres e nas quais as imagens de crianças ajudavam a compor a representação do ideário burguês (Figura 01) demonstram que ela se direcionava ao público feminino e que visava promover hábitos, comportamentos e atitudes, entre os quais o da valorização da leitura.

Figura 01: Família: representação do ideal burguês

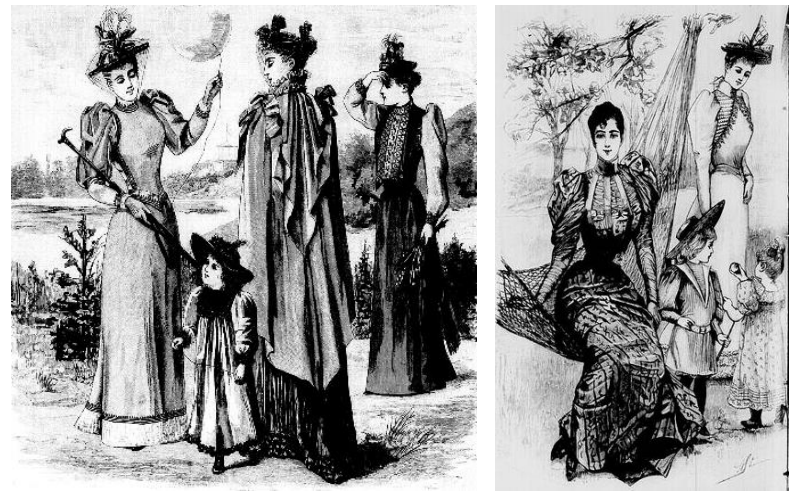

Fonte: A Estação, 31/05/1892, p. 76; 31/08/1892, p. 124

Os pontos de vista, expressos nas matérias da revista, eram prezados pela sociedade brasileira, que buscava sua legitimação por meio da identificação com o ideário burguês, de que a valorização da literatura fazia parte. Dessa forma, A Estação atendia aos anseios civilizatórios de um país que, entre outros aspectos de natureza sociocultural, investia no estabelecimento de um mercado editorial, mas que revelava contradições decorrentes de problemas de ordem conjuntural - como o do analfabetismo - ou estrutural - como o gerado por um sistema econômico embasado no trabalho escravo. Paralelamente, a adoção de práticas culturais estimuladas pela revista mostra que a institucionalização da identidade brasileira ocorria a partir de uma relação de submissão a culturas hegemônicas, particularmente a francesa, ainda que essa dependência pudesse ser representada, pela literatura, sob uma perspectiva irônica.

A aceitação da cultura proveniente da França ${ }^{3}$, que a revista representava, também se encontrava expressa na paisagem, por meio da urbanização e da arquitetura, nas artes plásticas e nos costumes. O Rio de Janeiro vivia

uma espécie de belle époque em ponto pequeno, com a multiplicação de confortáveis carruagens, as lojas de luxo no mais refinado gosto parisiense e as confeitarias onde se saboreavam novidades como o sorvete [...]. Abriam-se os grandes salões, servidos por escravos falando francês: oui, monsieur; vite, vite; je vous em prie; pardon, madame (MACHADO, 2000, p. 23).

Nesse ambiente de explícita adesão à cultura francesa no campo das artes, dos costumes, das ideias, a "Crônica da Moda" ou o "Correio da Moda", exibidos em todas as capas das edições da revista, informavam, aos leitores, tendências parisienses do vestuário, de decoração, de etiqueta e de comportamento, fato que é enfatizado pelo editor, estabelecendo-se uma correspondência entre suas palavras e as expectativas do público:

A moda, única soberana incontestada dos tempos atuais, a moda que da França irradia sobre todos os países, no que diz respeito às toilettes de senhoras e de homens, também de lá vem para determinar o uso, as regras das visitas. (A Estação, Correio da Moda, $15 / 12 / 1880$, p. 240$)^{4}$

\footnotetext{
${ }^{3}$ A Estação detinha, em 1882, 10.000 assinantes, número que se ampliava para 100.000 leitores conforme testemunha seu editor: "cada assinante representa, termo médio, dez leitores, o que nos dá uma circulação de 100 mil leitores, quando, aliás, a nossa tiragem é de apenas dez mil exemplares" (A Estação, $15 / 03 / 1883$, p. 52)

${ }^{4} \mathrm{O}$ registro linguístico das citações da revista foi adaptado à ortografia atual.
} 
A "Crônica de Moda" da edição de 30 de março de 1885 (Figura 02) exemplifica a orientação assumida pelo periódico: a ilustração define o modelo de vestido em voga e ressalta, por meio do piano, a classe social a que ele se destina, uma vez que esse instrumento passou a ser símbolo de evidência social (A Estação, 15/01/1879, p. 44).

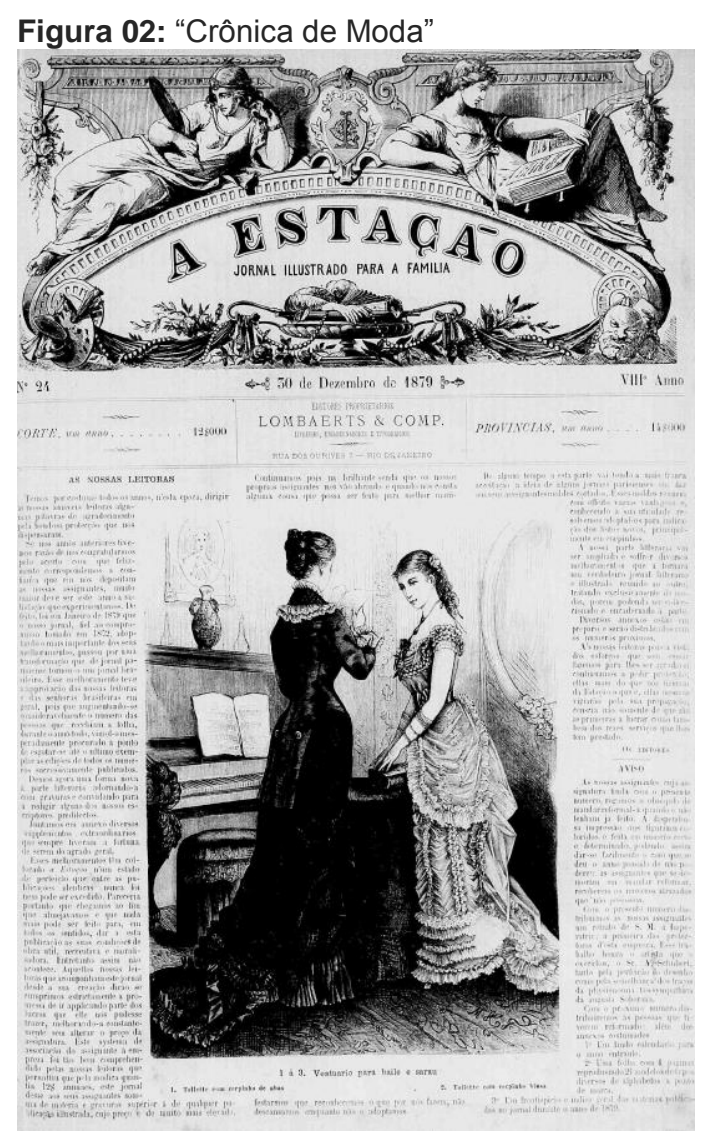

Fonte: A Estação, 30/03/1885, p.44.

A aceitação da moda migrava das páginas do periódico para as ruas do Rio de Janeiro, particularmente para a do Ouvidor, em que se localizavam modistas, cabeleireiros e lojas de artigos finos, grande parte delas pertencentes a franceses, e que tinham como clientela a elite da sociedade brasileira ${ }^{5}$. Distintas damas passeavam pelas ruas do Rio de Janeiro, sob um calor escaldante, com pesados e longos vestidos de estilo europeu; os homens usavam casacas, calças de casimira, botas e volumosos lenços, mesmo que o clima do Rio de

\footnotetext{
5 Laurence Hallewell descreve a rua do Ouvidor como uma extensão da França, referindo que, em 1862, de um total de 205 estabelecimentos comerciais aí instalados, 93 pertenciam a franceses (HALLEWELL, 2005, p.153-54).
}

Janeiro não fosse apropriado para esse tipo de indumentária.

Portanto, a contraposição entre a indumentária em uso e as sugestões do periódico revela que essas eram aceitas sem que houvesse a preocupação de adequá-las à realidade brasileira, visto que os habitantes do clima tropical submetiam-se ao vestuário próprio do temperado ou frio clima europeu. Assim, "mesmo que as mulheres elegantes da capital esperassem seis meses para estrear a moda de inverno parisiense, elas ainda estariam agasalhadas demais para o frio carioca" (FEIJÃO, 2011, p. 132), conforme mostra a Figura 03, que apresenta mulheres vestindo roupas com peles e tecidos próprios para o frio e patinando no gelo, atividade totalmente inexistente no Brasil.

Figura 03: llustração de moda

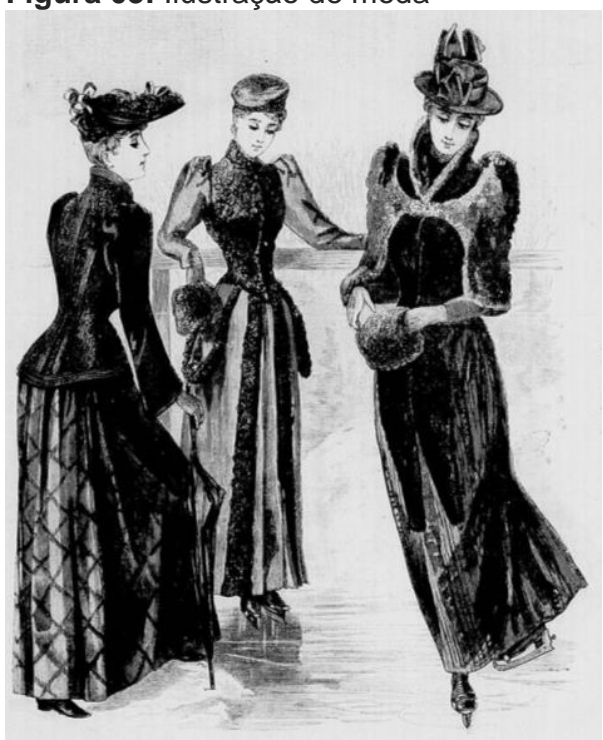

Fonte: A Estação, 31/01/1891, p.10.

Os conteúdos do "Jornal de Moda" não se restringiam, portanto, a informações sobre tendências do bem-vestir parisiense, confirmando a amplitude do espectro ideológico que a moda traduz. Assim, enquanto versavam sobre decoração, etiqueta, costumes e hábitos franceses, que eram difundidos por meio de artigos, ilustrações e anúncios, as matérias revelavam também aspirações da sociedade. Disso são exemplo os anúncios comerciais que abrangiam drágeas para combater o nervosismo e a epilepsia; xaropes para facilitar o surgimento dos dentes, para curar asma e 
enxaqueca; pílulas para tratar da gota, da influenza, do catarro; máquinas de costura, tecidos, espartilhos, acessórios, cremes de beleza capazes de remover todos os defeitos da pele, perfumarias, bonecas, além de pianos.

O piano seduzia as famílias brasileiras de maior poder aquisitivo e lhes conferia certa distinção, por estarem associadas a uma prática do universo cultural francês. Segundo Luís Filipe de Alencastro, a partir de 1850, o piano é "mercadoria-fetiche", e seu alto "valor agregado" e "efeito ostentatório" transformavam-no em "objeto de desejo dos lares patriarcais" (2001, p. 42-44). A presença habitual do piano nas casas da elite brasileira e sua valorização como objeto de status são registradas em fotografia feita por Marc Ferrez, em torno de 1886: ela mostra a princesa Isabel ao piano, acompanhada da baronesa de Muritiba, no interior do Palácio Isabel, atual Palácio Guanabara (Figura 04):

Figura 04: Princesa Isabel ao piano, fotografada por Marc Ferrez, 1886

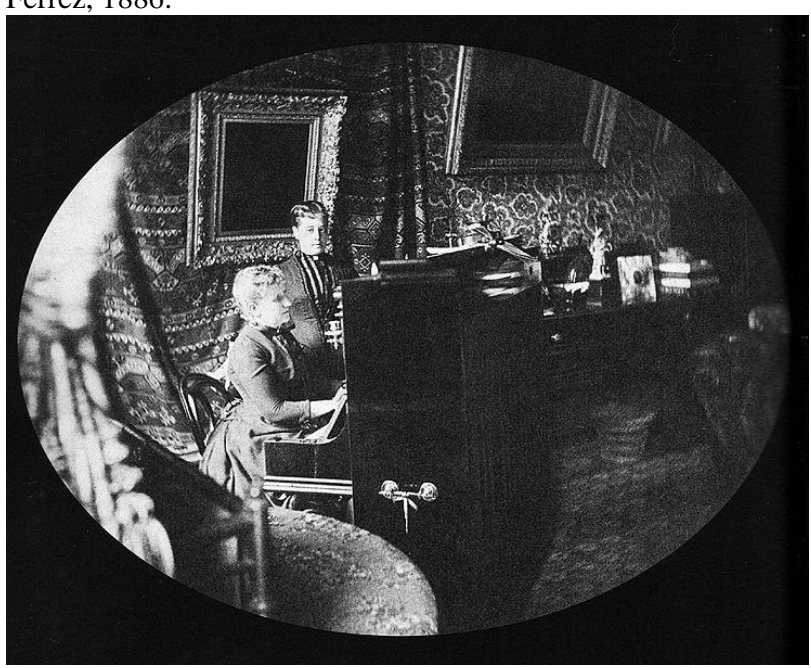

Fonte: http://www.mare.art.br/detalhe.asp?idobra=3264 Acesso em: 10 out. 2014

Entretanto, o investimento em pianos, estimulado pelo periódico, é emblema de um movimento mais amplo, pois, a partir da segunda metade do século $\mathrm{XIX}$, a música fazia parte da vida cultural do Rio de Janeiro. A sociedade privilegiava concertos, e a vida musical era dinamizada pela constituição de sociedades, que visavam difundir as produções eruditas, e pela visita de artistas de renome internacional (AZEVEDO, 1956). As educadas moças da sociedade brasileira tocavam piano em festas de família "e muitas delas, após o casamento, o levavam como um dote para as suas casas" (AMATO, 2007, p. 3). Os encontros familiares em torno do piano ou os saraus eram abertos à participação de convidados, e esses eventos "exerciam um papel fundamental em relação ao lazer da elite que, por este meio, apresentava suas filhas à sociedade, cultivava amizades e negócios num ambiente restrito e acolhedor, consolidando seus interesses e relações" (ARAUJO, 2012, p. 11). Assim, orientando-se pelo gosto de seu público e ajudando a instituí-lo, a revista $A$ Estação publicava partituras musicais no "Suplemento Literário", e, simultaneamente, ilustrações de moda que mostravam o uso do piano como um entretenimento associado ao luxo e ao bom gosto (Figura 05):

Figura 05: Uso do piano associado ao luxo e ao bom gosto

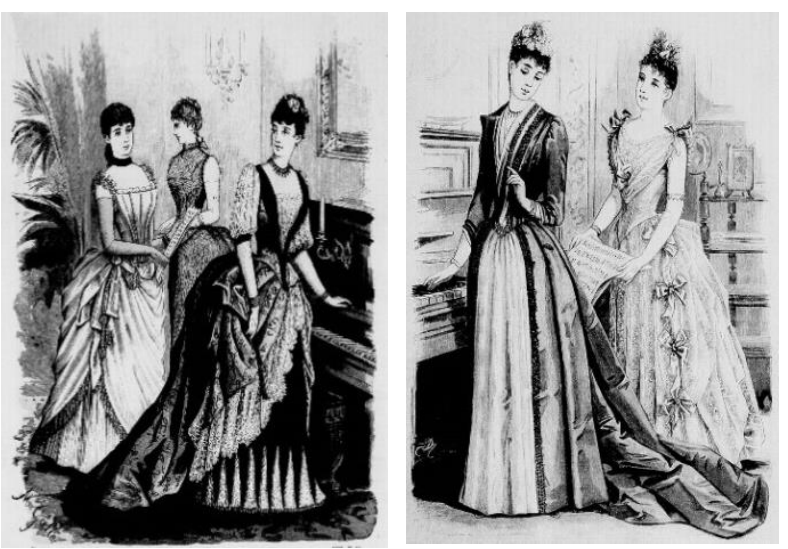

Fonte: A Estação, 31/10/1886, p. 38; 15/03/1889, capa.

A valorização do piano na formação de jovens e a realização de saraus musicais e literários podem ser comprovadas em obras literárias, estabelecendose uma convergência entre 0 propósito de disseminação da cultura burguesa, assumido pelo periódico, e o desejo de "ilustração" da classe senhorial, que a literatura representava. Portanto, o "Jornal de Moda" e o "Suplemento Literário" articulavam-se na medida em que produções literárias refletiam o contexto histórico, social e estético em que os escritores se situavam e com o qual eles dialogavam. 
Entretanto, o "Suplemento Literário" não só conferiu um caráter localista ${ }^{6}$ ao periódico, como também contribuiu para seu sucesso, já que a participação de autores renomados the permitia alcançar um público mais abrangente, aumentando o número de leitores, granjeando mais anunciantes, e, ainda, favorecendo os escritores, que ganhavam maior visibilidade.

Além dos diferentes gêneros, que nele eram publicados, o suplemento também investia na valorização do livro e da leitura, na forma de estímulos à sua aquisição, iniciativa para a qual a parte dedicada à moda também contribui, por meio de mensagens do editor, como se constata na passagem a seguir:

As obrigações sociais que o uso criou para as festas de Natal e do Ano Bom, acompanham a todos em toda parte. No nosso século de divulgação da luz intelectual, de vulgarização dos conhecimentos artísticos e científicos, não há presente mais apropriado para todas as idades e condições do que o livro. (A Estação, "Correio da Moda", 15/12/1882, p. 269)

Nas páginas do "Suplemento Literário", são frequentes imagens de mulheres e crianças com livros nas mãos e com um semblante concentrado na leitura (Figura 06), e anúncios de livrarias, de lançamentos de livros, de revistas; resenhas sobre publicações recentes também ganham espaço, na forma de comentários.

Portanto, a revista $A$ Estação, ainda que disseminasse práticas culturais que destoavam da sociedade brasileira, ajudava a moldar a vida literária e motivava a população para a prática leitora, visto que exercia um apelo incisivo, devido à publicação de anúncios de livrarias, de comentários sobre obras em circulação e, sobretudo, devido à publicação de textos literários, entre os quais os romances em folhetim.

\footnotetext{
${ }^{6}$ Referindo-se à publicação do suplemento e comparando-o com a parte dedicada à moda, afirma o editor: "Por esse lado continuará o nosso jornal a ser parisiense. Por outro lado, porém, na arte agradável e recreativa, devíamos torná-lo nosso, e assim o fazemos. Confiamos a parte literária de $A$ Estação a pessoas de reconhecida habilidade" ( $A$ Estação, 15/01/1879, p. 1).
}

Figura 06: Imagens de estímulo à leitura e publicidade de livros

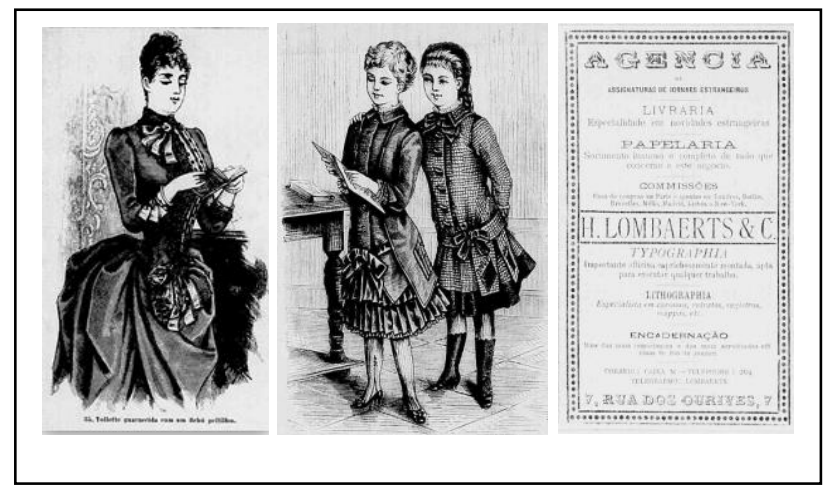

Fonte: A Estação, 31/03/1887, 15/03/1883, 15/01/1895

\section{Romance Quincas Borba e denúncia da submissão ideológica, expressa em A Estação}

As páginas de $A$ Estação serviram de veículo para a divulgação de inúmeros textos literários de Machado de Assis. Nelas, o escritor publicou 37 contos, entre 1879 e 1898 (GLEDSON, 1998, p. 17), e alguns deles viriam a compor as coletâneas Papéis Avulsos, Histórias sem Data e Relíquias de Casa Velha. Entre 1881 e 1882, "O Alienista" foi publicado, em fascículos, na revista e, entre 1885 e 1886, a novela Casa Velha; de 15 de junho de 1886 até 15 de setembro de 1891, o periódico veiculou Quincas Borba, também em secções. No periódico, Machado também publicou produções de gêneros variados, tais como crítica, resenhas, editoriais, traduções, ensaios.

O romance Quincas Borba foi reimpresso em livro pela Lombaerts, para a Garnier, vindo a público no mesmo mês em fora concluída a publicação da narrativa em fascículos. Em ambas as versões, é narrada a história de Rubião, o ingênuo professor de Minas que almeja brilhar na corte do Rio de Janeiro, apoiado na fortuna e na filosofia herdadas de Quincas Borba, mas que, submetido a um processo de espoliação, chega à miséria e à loucura (ASSIS, 1986). Todavia, a presença do mesmo argumento não esmaece as mudanças que distinguem estrutural e discursivamente o texto publicado em folhetim, do publicado em livro. Alterações revelam o posicionamento crítico do escritor diante do comportamento da classe burguesa e, por extensão, 
dos prováveis leitores de A Estação, podendo essas ser exemplificadas pela exclusão de episódios e por mudanças de natureza lexical. A transposição de comportamentos, a descrição do vestuário feminino e a temática da narrativa, idênticas em ambas as versões, também convergem para o contexto do periódico e da sociedade, estabelecendo-se um processo de simbiose entre esta e aquele.

O confronto entre as duas versões evidencia não apenas a alteração estrutural pelo deslocamento, por exemplo, dos capítulos XX, XXI, XXII e XXIII para comporem os capítulos I, II e III do livro, mas também a transformação ou eliminação de episódios do folhetim que acentuam o cunho fabuloso e o apelo emocional, traços que podem ser relacionados com o leitor do periódico. Assim, a passagem em que uma carta de Sofia, a protagonista, endereçada a Carlos Maria, chega, acidentalmente, às mãos de Rubião, estimulando-o a imaginar uma relação adúltera entre a mulher e o rapaz, difere de uma versão para outra. Na publicada em A Estação, Rubião arma-se com um revólver para ameaçar ou matar Sofia, caso ela tente subtrair-Ihe a carta. Uma vez desfeito o equívoco, visto que a missiva era a circular de uma comissão instituída para angariar fundos para os desafortunados de Alagoas, Rubião pede perdão a Sofia, derramando lágrimas copiosas. Em outro episódio, totalmente excluído da versão em livro, Palha, desconfiando de que Sofia cedera à paixão de Rubião, imagina uma forma de matar seu sócio e, simultaneamente, decide perdoar a mulher, caso ela o peça.

As alterações da história, de que resultam mudanças nas ações dos protagonistas e em sua caracterização, eliminam o teor excessivamente sentimental e o tom melodramático da primeira versão, tão ao gosto dos leitores de folhetim. Elas traduzem a rejeição de Machado por uma linha temática que ele explorara na publicação seriada e na qual enfatizara a comoção e o arrebatamento dos protagonistas, características condizentes com 0 melodrama ou com uma literatura de forte apelo popular. Essas características se ajustavam às expectativas dos leitores reais do folhetim, que buscavam, nas páginas dos fascículos, aventuras capazes de ativar a emoção e o suspense, alimentados por julgamentos equivocados, os quais quase se consumam em tragédia, por traições, por crimes, mas também por gestos magnânimos de perdão.

A narrativa, em ambas as versões de Quincas Borba, também traduz o posicionamento de leitores de A Estação quanto a comportamentos sociais e, para tanto, como se fosse uma extensão dos anúncios do periódico, parece propagar o prestígio da cultura francesa. Em uma passagem do romance, Sofia expõe à tia a necessidade de a prima, Maria Benedita, saber tocar piano e falar francês, para preparar-se para a vida na Corte. A tia e a prima, a qual nascera na roça e lá se criara, não compartilham da opinião de Sofia, instalando-se o embate a partir das duas posições divergentes. O narrador transpõe a situação conjugando, ao discurso indireto, o indireto livre e o direto, para enfatizar, por meio da pluralidade de vozes, a perspectiva irônica com que avalia a subordinação da elite carioca, tão bem representada por Sofia, à cultura hegemônica da França:

Nem piano nem francês, - outra lacuna, que Sophia mal podia desculpar. D. Maria Augusta não compreendia a consternação da sobrinha. Para que francês? A sobrinha dizia-lhe que era indispensável para conversar, para ir às lojas, para ler um romance [...].- Sempre fui feliz sem francês, respondia a velha; e os meia-línguas da roça são a mesma cousa; nem por isso lhe hão de faltar noivos. - Mas se o marido é juiz de direito, ponderava Sophia”. (Q.B., A Estação, 15 mai. 1887, p.87)

Se 0 francês era necessário para a conversação, para a visita às lojas, para a leitura de romances, sendo condição para um casamento vantajoso, Machado assinala seu uso pela recorrência à língua francesa, na versão em folhetim. Todavia, na reescrita do romance, o escritor substitui termos franceses por equivalentes em português, como "petit-pois" por "ervilhas" e "monsieur" por "senhor". A opção pelo emprego de vocábulos franceses na primeira versão se justificava pelo contexto da sociedade carioca da segunda metade do século XIX, em que a influência da França se 
expunha nas artes, na moda, nos costumes, e, sobretudo, na circulação de obras e de periódicos, de que $A$ Estação é exemplo. Entretanto, o escritor tem consciência da perenidade desse veículo quando contraposto à materialidade do livro, razão por que ele elimina, do texto publicado em livro, aspectos que atendiam a expectativas do público leitor do periódico e que confirmavam sua submissão a modelos culturais estrangeiros, como o expresso no uso de estrangeirismos.

O vestuário feminino do romance parece duplicar, por palavras, as imagens apresentadas na revista $A$ Estação, ainda que sua descrição seja pouco detalhada. No início da narrativa, quando Rubião reflete sobre o rumo a dar à vida, após ter ficado rico, a sedução do Rio de Janeiro - "com os seus feitiços, movimento, teatros em toda a parte, moças bonitas, vestidas à francesa" (Q. B., $A$ Estação, 15/08/1886, p. 57) - impele-o a abandonar Barbacena, para integrar-se ao que supõe ser um espaço de luxo e esplendor. Já na capital do Império, em visita ao casal Palha, os olhos de Rubião detalham a imagem de Sofia, que contrasta com a do primeiro encontro, no trem de Vassouras: "Lá vestia a capa, embora tivesse os olhos descobertos; cá trazia à vista os olhos e o corpo, elegantemente apertado em um vestido de cambraia, mostrando as mãos que eram bonitas, e um princípio de braço." (Q. B., A Estação, 15/09/1886, p. 65). Em outra passagem, a descrição física de Sofia é completada pelo narrador com a seguinte observação: "Traja bem; comprime a cintura e o tronco no corpinho de lã fina cor de castanha, obra simples, e traz nas orelhas duas pérolas verdadeiras" (Q. B., A Estação, 15/11/1886, p. 81). Também Teófilo, marido de D. Fernanda, envolve Sofia com um olhar de admiração, assinalando que "o vestido sublinhava admiravelmente a gentileza do busto, o estreito da cintura e o relevo delicado das cadeiras; era foulard, cor de palha" (Q. B., A Estação, 30/11/1890, p. 101).

Vestidos, joias, chapéus, meias de seda, sapatos rasos, botas, roupas ajustadas ao corpo, seios à mostra ajudam a compor a figurativização de Sofia, que é exposta como um objeto, pelo marido, que gostava de "aparecer com os olhos da mulher, os olhos e os seios", e, para tanto, ele "decotava a mulher sempre que podia, e até onde não podia, para mostrar aos outros as suas venturas particulares" ( $Q$. B., A Estação, 15/11/1886, p. 81). Com efeito, a representação da personagem Sofia é um prolongamento das imagens impressas em $A$ Estação, todavia, inserida no universo da narrativa, essa representação introduz avaliações de natureza moral e ética. Assim, Sofia, reificada pelo marido, harmoniza-se com a arrivista social que, ao alcançar novo status, desconhece as amizades antigas, de modo que "uma por uma, se foram indo as pobres criaturas modestas, sem maneiras, nem vestidos, amizades de pequena monta, de pagodes caseiros, de hábitos singelos e sem elevação" (Q. B., A Estação, 15/04/1890, p. 25). Portanto, na totalidade do texto, Sofia - mestre na exibição de figurinos franceses e na exclusão de indesejados, cuja vestimenta é índice de seu lugar na escala social - é denunciada pelo narrador que expõe sua falsa identidade, mera máscara revestida de atributos que não lhe pertencem.

Sob essa perspectiva, a adoção, por Rubião, em seu delírio, primeiro da identidade de Napoleão e depois de Luís Napoleão - cujo modelo abstrai de um busto em mármore - enfatiza o mascaramento de uma sociedade que faz da cópia seu traço peculiar. Entrevistos como uma possível extensão das ilustrações de $A$ Estação, os bustos de mármore dos imperadores franceses estão fora de lugar, como estão os modelos de roupas femininas, com que mulheres ilustres desfilam nas ruas do Rio de Janeiro. Assim, enquanto Rubião assume, em seu desvario, uma imagem em que a semelhança é incapaz de anular as diferenças, a assimilação, pela sociedade brasileira, de práticas da cultura europeia também não consegue apagar as marcas da inadequação e assinala a falta de autenticidade. Consequentemente, se Rubião, travestido de imperador, expõe o desacordo entre realidade e aparência, este se estende à concepção da sociedade que, submetendose a uma cultura hegemônica, revela as fissuras entre 
a identidade que deseja manifestar e aquela que, efetivamente, é capaz de assumir.

Portanto, entrevista a partir do processo de civilização ou de submissão cultural que o próprio periódico enfatiza ao alegar que seu objetivo é ser útil, recrear e moralizar, a publicação de Quincas Borba, em A Estação, também deve ser avaliada a partir de dupla dimensão. Por um lado, o romance de Machado mostra a natural dependência da sociedade brasileira, ainda em formação, de modelos a serem imitados, para chegar a constituir um povo culto; por outro, ele denuncia a subserviência cultural e avalia os comportamentos sociais, para instituir uma reflexão crítica sobre o fascínio do luxo e do poder, sobre o apego à aparência e o menosprezo pela substancialidade. Paradoxalmente, ambas as dimensões são sustentadas pelo romance de Machado, mas a segunda ganha uma notação singular, porque solapa os valores do próprio veículo em que se inscreve, isto é, de A Estação, apontando para sua inadequação e artificialidade, em face da sociedade brasileira.

A denúncia da propagação de práticas culturais alienantes não elide, porém, a contribuição da revista da Lombaerts à cultura brasileira: configurando-se como um periódico transnacional, orientado por uma visão mercantilista, A Estação introduzia, no Brasil, uma visão estrangeira, sem nenhuma preocupação com os problemas nacionais, mas, ao mesmo tempo, incentivava a literatura nacional, contribuindo para a formação de um público leitor.

Outro aspecto, cuja avaliação é ambivalente, refere-se à orientação do periódico para o público feminino. Cartas, editoriais, comentários, as ilustrações de moda endereçavam-se a ele; parte do periódico expunha itens de decoração e a maioria dos anúncios - utensílios de maquiagem, espartilhos, perfumes, drágeas medicamentosas - tinham a mulher como foco. Igualmente, o romance folhetim de Machado de Assis, reportava-se, frequentemente, a uma leitora fictícia, enfatizando a hipótese de que o veículo se orientava precipuamente para o público feminino. Sob essa perspectiva, $A$ Estação reconhecia a importância das mulheres na introdução de práticas culturais e, embora concebesse o gênero feminino como sendo facilmente influenciável, admoestava as leitoras, por meio de editoriais, a assumirem uma posição de independência em face da moda e de alternativas de decoração doméstica, ao mesmo tempo em que acolhia publicações de mulheres, contribuindo para a emancipação feminina pelo próprio ato de escrever e de publicar.

Em síntese, o valor histórico da revista $A$ Estação é evidente, uma vez que, conjugando-se a circunstâncias de natureza cultural e social, buscou contribuir para a constituição de uma sociedade familiarizada com a cultura das letras, da arte pictórica, musical e dramática e que privilegiasse o consumo de bens. Portanto, ela influenciou a concepção da identidade brasileira, que assimilava modelos europeus e os integrava ao cotidiano, em um momento em que a construção de um modo de vida próprio e singular ainda estava em processo.

\section{Referências}

A Estação. Disponível em: <http:/wwwhemerotecadigital.Bn.Br>. Acesso em: 14 out. 2014

ALENCASTRO, Luíz Felipe de. História da vida privada no Brasil. Império: A corte e a modernidade nacional. São Paulo: Companhia das Letras, 2011.

AMATO, Rita de Cássia Fucci. O piano no Brasil: Uma perspectiva histórico-sociológica. Disponível em: $<$ http://antigo.anppom.com.br/anais/anaiscongresso anppom 2007/musicologia/musicol RCFAmato 1.pdf >. Acesso em: 16 set. 2014

ARAUJO, Jander Antonio Sá de. A poética do sarau em A Moreninha: Liturgia e semiose. 2012. Disponível em:

<http://www.bdtd.ndc.uff.br/tde_busca/processaPesqu isa. php?pesqExecutada=1\&id=3495>. Acesso em: 20 ago. 2014

ASSIS, Machado de. Quincas Borba. In: Obra Completa. Rio de Janeiro: Nova Aguilar, V. I, 1986, p. 643-806.

AZEVEDO, Luiz Heitor Correa de. 150 Anos de música no Brasil. Rio de Janeiro: José Olympio, 1956.

BORGES, Valdeci Rezende. Meios de comunicação da cultura escrita na Corte Imperial. OPSIS. Revista do NIESC, Vol. 5, 2005, p. 75-88. 
FAUSTO, Boris. História do Brasil. São Paulo: Edusp, 2012.

FEIJÃO, Rosane. Moda e modernidade na belle époque carioca. São Paulo: Estação das letras e cores, 2011.

GLEDSON, John. Os contos de Machado de Assis. In: ASSIS, Machado de. Contos: Uma Antologia, Volume I. São Paulo: Companhia das Letras, 1998.

HALLEWELL, Laurence. O livro no Brasil: sua história. São Paulo: Edusp, 2005.

MACHADO, Ubiratan. A vida literária no Brasil durante o Romantismo. Rio de Janeiro: Tinta Negra Bazar Editorial, 2000.

MASSA, Jean-Michel. A Juventude de Machado de Assis: 1839-1870. Rio de Janeiro: Civilização Brasileira, 1971.

MEYER, Marlyse. Caminhos do imaginário no Brasil. São Paulo: Edusp, 1993.

SILVA, Ana Cláudia Suriani da. Moda e literatura: O caso da Revista A Estação. lara - Revista de moda, cultura e arte. São Paulo: Vol. 2, N.1, Set/Dez. 2009.

SODRÉ, Nelson Werneck. Síntese de história da cultura brasileira. Rio de Janeiro: DIFEL, 1982. 